\begin{tabular}{|l|l|l||}
\hline \multicolumn{2}{|c|}{ PublisherInfo } \\
\hline \hline PublisherName & $:$ & BioMed Central \\
\hline \hline PublisherLocation & $:$ & London \\
\hline \hline PublisherImprintName & $:$ & BioMed Central \\
\hline \hline
\end{tabular}

\title{
Breeding a better vector
}

\begin{tabular}{|l|l|l||}
\hline \multicolumn{2}{|c|}{ ArticleInfo } \\
\hline \hline ArticleID & $:$ & 3738 \\
\hline \hline ArticleDOI & $:$ & $10.1186 /$ gb-spotlight-20000807-01 \\
\hline \hline ArticleCitationID & $:$ & spotlight-20000807-01 \\
\hline \hline ArticleSequenceNumber & $:$ & 175 \\
\hline \hline ArticleCategory & $:$ & Research news \\
\hline \hline ArticleFirstPage & $:$ & 1 \\
\hline \hline ArticleLastPage & $:$ & 2 \\
\hline \hline & & RegistrationDate : 2000-08-07 \\
ArticleHistory & $:$ & OnlineDate $\quad$ 2000-08-07 \\
\hline \hline ArticleCopyright & $:$ & BioMed Central Ltd2000 \\
\hline \hline ArticleGrants & $:$ & \\
\hline \hline ArticleContext & $:$ & 130591111 \\
\hline \hline
\end{tabular}




\section{William Wells}

Email: wells@biotext.com

DNA shuffling (also called molecular breeding) generates variation by random fragmentation of a cloned gene followed by reassembly of the fragments in a self-priming polymerase reaction. The result is a recombination of overlapping fragments that have different mutations or come from different, naturally occurring homologous genes. In the August Nature Genetics Soong et al. apply this technique to a pool of six different murine leukemia virus envelope sequences to derive a new virus that can, unlike its parents, infect Chinese Hamster Ovary (CHOK1) cells (Nat. Gen. 2000, 25:436-439). Similar selections on clinically relevant cell types may yield improved vectors for gene therapy.

\section{References}

1. Rapid evolution of a protein in vitro by DNA shuffling.

2. DNA shuffling of a family of genes from diverse species accelerates directed evolution.

3. Nature genetics, [http://www.nature.com/ng/] 